\title{
超音波検査による肩腱板断裂の診断精度
}

\author{
時 吉 聡 介* 井手 淳 二** 廣 瀬 隼 ${ }^{* *}$ 水 田 博 志**
}

\section{Accuracy of Ultrasonography of the Shoulder for the Diagnosis of Full Thickness Rotator Cuff Tear}

\begin{abstract}
Akinari Tokiyoshi*, Junji Ide**, Jun Hirose**, and Hiroshi Mizuta**
【目的】超音波検查は侵襲が少なく，外来で検査が可能であり，非常に簡便な検查法である，当施設で行つ た超音波検查の正診率について検討した。【対象と方法】平成 19 年 3 月から 11 月までに熊本大学医学部 附属病院にて肩関節鏡視下手術を行った 28 人（男性 16 人，女性 12 人，平均年齢 52.3 歳）を対象とした. 超音波検查を術前に行い，腱板断裂の有無を肩甲下筋腱，棘上筋腱，棘下筋腱おのおのについて診断した. 最終的な診断は手術時の所見とし感度, 特異度, 正診率を算出した。【結果と考察】肩甲下筋腱；感度は $100 \%$, 特異度 $92.0 \%$, 正診率 $92.9 \%$ であった。 棘上笳腱；感度は $93.3 \%$ ，特異度 $84.6 \%$, 正診率 $89.3 \%$ であつた，棘下筋腱；感度は $36.4 \%$ ，特異度 $100 \%$ ，正診率 $75.0 \%$ であつた，我々の結果は諸家の報告 と比べてやや低い傾向にあった．正診率を挙げるためには今後もトレーニングが必要と考えられた.
\end{abstract}

Purpose: To evaluate the accuracy of ultrasonography in the detection of full-thickness rotator cuff tear.

Materials and Methods: Preoperative ultrasonography with $8 \mathrm{MHz}$ linear-array transducer was performed in 28 shoulders on 28 hospitalized patients. All patients were operated arthroscopically. We have diagnosed cuff tears on subscapularis, suprasupinatus, and infrasupinatus tendon. The presence of a full-thickness rotator cuff tear demonstrated by arthroscopy was recorded as the final diagnosis.

Result: Ultrasonography correctly diagnosed three full-thickness subscapularis tendon tears with $100 \%$ sensitivity, $92.0 \%$ specificity, and $92.9 \%$ accuracy, 14 of 15 suprasupinatus tendon tears $(93.3 \%$ sensitivity, $84.6 \%$ specificity, and $89.3 \%$ accuracy) and four of 11 infrasupinatus tendon tears (36.4\% sensitivity, 100\% specificity, and $75 \%$ accuracy).

Conclusion: The accuracy of full-thickness rotator cuff tears in the suprasupinatus and subscapularis tendons was as high as previously reported rates. It was difficult to detect tears in the infraspinatus tendon because of the limitation of ultrasonography. We plan to perform the ultrasonography in other outpatients to enhance the accuracy of the diagnosis of rotator cuff tears.

Key words : rotator cuff tear (肩腱板断裂), ultrasonography (超音波検查), accuracy（診断精度）

\section{は じめに}

超音波検査は簡便で人体に対する侵襲が少なく繰り 返し検査が可能であり, さらにはリアルタイムでの動 きも加味した画像検査である. 循環器, 消化器, 泌尿 器などでは日常診療に欠かせないものとなっている. 一方, 整形外科領域ではいまだその利用率は低い.
しかしながら，肩関節は比較的浅い位置にあり，滑 液包があるという超音波検査に適した領域であり， 1980 年代のはじめから米国では観察が行われている. このような経緯から, 整形外科領域の中では比較的超 音波検查が繁用されている領域であり, 本誌でも数々 の発表がなされている.

超音波検査は非常に簡便であるが，その精度は諸家

\footnotetext{
* 熊本市民病院整形外科 Department of Orthopaedic Surgery, Kumamoto City Hospital, Kumamoto, Japan

** 熊本大学大学院運動骨格病態学分野 Department of Orthopaedic and Neuro-Musculoskeltal Surgery, Faculty of Medical and Pharmaceutical Sciences, Kumamoto University, Kumamoto, Japan
} 
の報告により様々である，我々は熊本大学医学部附属 病院で行つた肩関節の超音波検査による肩腱板断裂の 診断精度について検討した.

\section{対象と方 法}

対象は平成 19 年 3 月から 11 月までに熊本大学医学 部附属病院にて肩関節鏡視下手術を行つた 28 人（男 性 16 人, 女性 12 人, 平均年歯 52.3 歳 ; 16 歳 73 歳) である. 外来での診断結果は知らせず, 入院後肩関節 の診察を行つたあとで超音波検査を行つた.

超音波検査は東芝社製の SSA-340A（8 MHz，リニ アプローベ）を用いて，棘上筋腱，棘下筋腱，肩甲下 筇腱それぞれについて短軸，長軸とも検査を行い，完 全断裂があるものを断裂ありとした． 棘下筋腱は肩甲 棘よりも尾側と定義した.

最終的な診断は肩関節鏡検査にて行い, 棘上筋腱, 棘下筋腱, 肩甲下筋腱のそれぞれについて感度, 特異 度, 正診率を算出した.

\section{結果}

肩甲下筋腱（表 1)

関節鏡所見で断裂を認めたものは 3 例であった. 感 度は $100 \%$, 特異度 $92.0 \%$, 正診率 $92.9 \%$ であった。
棘上筋腱（表 2)

関節鏡所見で断裂を 15 例で認めた。超音波検査で の偽陽性が 2 例，偽陰性が 1 例あった。感度は 93.3 \%, 特異度 $84.6 \%$, 正診率 $89.3 \%$ であつた.

棘下筋腱 (表 3)

関節鏡所見で断裂ありと診断したものは 11 例であつ た．偽陽性の症例はなかつたが，偽陰性が 7 例と多かっ た. 陽性的中の 4 例の内 3 例は断裂の大きさが $5 \mathrm{~cm}$ を超える広範囲断裂であった。 一方, 偽陰性となった 7 例は全て $5 \mathrm{~cm}$ を超えない大断裂もしくは中断裂で あった，感度は $36.4 \%$, 特異度 $100 \%$, 正診率 $75.0 \%$ であった.

$$
\text { 考察 }
$$

これまでの報告では肩甲下筋腱，棘上筋腱，棘下筋 腱と分けて検討してあるものは少なく，主に腱板断裂 の有無について検討されている. Sharlene ら ${ }^{6)}$ は感 度 $97 \%$, 特異度 $67 \%$, 正診率 $94 \%$ と報告している。 Milosavljevic ら ${ }^{4)}$ は感度 $95 \%$ ，特異度 $94 \%$, 正診率 95\% と報告している. Ianotti ら ${ }^{2)}$ は感度 $88 \%$ ，特異 度 $80 \%$, 正診率 $96 \%$ と報告している。これらの報告 結果は, 我々の棘上筋腱の結果と近いものと考えてい る.ただし，本調査は外来診療ではなく，手術予定で

表 1 肩甲下筋腱

\begin{tabular}{cccc}
\hline \hline & 鏡視にて断裂あり & 鏡視にて断裂なし & 合計 \\
\hline 超音波にて断裂あり & 3 & 2 & 5 \\
超音波にて断裂なし & 0 & 23 & 23 \\
\hline 合計 & 3 & 25 & 28 \\
\hline
\end{tabular}

表 2 棘上筋腱

\begin{tabular}{cccc}
\hline \hline & 鏡視にて断裂あり & 鏡視にて断裂なし & 合計 \\
\hline 超音波にて断裂あり & 14 & 2 & 16 \\
超音波にて断裂なし & 1 & 11 & 12 \\
\hline 合計 & 15 & 13 & 28 \\
\hline
\end{tabular}

表 3 棘下筋腱

\begin{tabular}{cccc}
\hline \hline & 鏡視にて断裂あり & 鏡視にて断裂なし & 合計 \\
\hline 超音波にて断裂あり & 4 & 0 & 4 \\
超音波にて断裂なし & 7 & 17 & 24 \\
\hline 合計 & 11 & 17 & 28 \\
\hline
\end{tabular}


入院した患者を対象としたため特異度が低くなったも のと推察する.

肩甲下筋腱の超音波検査では偽陽性が 2 例みられた. 肩甲下筋腱の断裂を診る際には肩関節を内外旋しなが ら行う。患者は多かれ少なかれ可動域制限があり, こ のことが診断できなかったことの原因になっているも のと考えられる. また，肩甲下筋腱の断裂は頭側に起 こり，尾側の筋性部分には起きにくいことが報告され ている ${ }^{377}$. 頭側の断裂部分に注意が向き過ぎた結果, 正常組織を断裂と診断した可能性があると考えられる.

今回検討した中で棘下筋の診断精度が最も低かつた. 特に偽陰性の数が多かった。この原因として断裂の大 きさの問題が挙げられる. 広範囲断裂では棘下筋の断 裂も大きく，結果として肩甲棘よりも尾側まで断裂が 広がり超音波プローべで確認できる結果になったと考 えられる。

Mochizuki ら ${ }^{5)}$ は屍体肩を詳細に観察し，棘下筋腱 は大結節の Superior facetに広く停止していること を報告している．我々は鏡視所見における筋線維の方 向によって腱を同定した。従って鏡視所見は Mochizuki ら ${ }^{5)}$ の報告に沿った形になっているものと 考えられる. 一方, 超音波検査においては, 筋線維方 向は不明であるため肩甲棘との位置関係のみで判断し た. 両者のズレが結果的に多くの偽陰性を引き起こし たものと判断した. Mochizuki ら5) の報告から考えれ ば棘上筋, 棘下筋の区別は超音波検査では不可能であ り，またあまり意味のないものと思われる．両者の区 別に重きをおくことなく, 今後は純粋に断裂の大きさ について短軸での所見を重視しながら検討して行きた いと考えている.

我々の結果では諸家の報告よりも精度が劣つていた. 診断精度に関しては Fontiadou ら ${ }^{1)}$ は診断精度が低 下するのは手技的な問題があると述べている.

Sharlene $ら^{6)}$ は肩関節の超音波検査の習得には long learning curveが必要と述べている. Ianotti らも 洗練された検者によって腱板断裂の正確な診断が可能 であると述べている．これらのことから，超音波検査 には熟練を要することが考えられ，今後はさらにトレー ニングを行う必要がある.

MRI の急速な普及により肩腱板断裂の画像診断が
比較的容易に行われるようになってきた。しかしなが ら MRI 検査の精度も $100 \%$ ではない22. また，MRI はあくまでも静止画像であり，動かしながらの検査は 不可能である．また費用も高く（1300 点），ペースメー カー使用中の患者や最近では改善されつつあるが閉所 恐怖症の患者には使用できない。，一方，超音波検査は 特別なスペースは不要でありランニングコストも安い. 検査費用も安く (350 点), 侵襲も少なく, リアル夕 イムで結果が分かるため繰り返し検査を行うことが可 能である，超音波検査の利点は多いが，最も問題とな るのはその診断精度である. MRI と同等の精度であ れば将来的には MRI は不要であり, 超音波検査結果 のみで関節鏡検査，鏡視下手術を行うことが可能とな ると考えている. 我々の結果は手技的に未熟な部分が あり, 高い診断精度ではないが今後のトレーニングに よって精度を挙げていけるものと考えている.

\section{参考文 献}

1) Fontiadou, A. N., et al.: Ultrasonography of symptomatic rotator cuff tears compared with MR imaging and surgery. Eur. J. Radiol., 68 : 174-179, 2008.

2) Ianotti, J.P., et al.: Accuracy of Office-Based Ultrasonography of the Shoulder for the Diagnosis of Rotator Cuff Tears. J. Bone Joint Surg. Am., 87 : 1305-1311, 2005.

3) Ide, J., et al.: Arthroscopic repair of traumatic combined rotator cuff tears involving the subscapularis tendon. J. Bone Joint Surg. Am., 89 : 2378-2388, 2007.

4) Milosavljevic, J., Elvin, A., Rahme, H.: Ultrasonography of Rotator Cuff; a Comparison with Arthroscopy in One-Hundred-and-Ninety Consecutive Cases. Acta Radiol., $8: 858-865,2005$.

5) Mochizuki, T., et al.: Humeral Insertion of the Supraspinatus and Infraspinatus. New Anatomical Findings Regarding the Footprint of the Rotator Cuff. J. Bone Joint Surg. Am., 90 : 962-969, 2008.

6) Sharlene, A., et al.: Detection and Quantification of Rotator Cuff Tears. Comparison of Ultrasonographic, Magnetic Resonance Imaging, and Arthroscopic Findings in Seventy-one Consecutive Cases. J. Bone Joint Surg. Am., 86 : 708-716, 2004.

7）時吉聡介ら：ヒト肩甲下筋の停止形態について. 関節 鏡, $33: 1-14,2008$. 